\title{
Pengaruh Board Diversity dan Intellectual Capital Pada Nilai Perusahaan
}

\author{
I Gusti Agung Rai Kristina ${ }^{1}$ \\ I Dewa Nyoman Wiratmaja ${ }^{2}$
}

\author{
${ }^{1}$ Fakultas Ekonomi dan Bisnis Universitas Udayana (Unud), Bali, Indonesia \\ email : raikristina3@gmail.com/Telp.+6281 237927751 \\ ${ }^{2}$ Fakultas Ekonomi dan Bisnis Universitas Udayana (Unud), Bali, Indonesia
}

\begin{abstract}
ABSTRAK
Penelitian ini bertujuan untuk membuktikan secara empiris pengaruh board diversity danintellectual capital pada nilai perusahaan. Penelitian menggunakan metode purposive sampling dimana dari 153 perusahaan manufaktur yang terdaftar di Bursa Efek Indonesia menjadi populasi diperoleh 56 perusahaan selama 5 tahun berturut-turut, sehingga total sampel sebanyak 280 sampel. Dengan menggunakan analisis regresi linear berganda, didapatkan hasil bahwa keberadaan dewan komisaris berkewarganegaraan asing dan intellectual capital berpengaruh positif signifikan pada nilai perusahaan. Namun, keberadaan dewan komisaris wanita, latar belakang pendidikan dewan komisaris, umur dewan komisaris, dan proporsi dewan komisaris independen tidak berpengaruh pada nilai perusahaan.

Kata kunci: Board diversity, intellectual capital, Tobin's $Q, V A I C^{T M}$
\end{abstract}

\begin{abstract}
This researchis purposed to prove empirically the effect of board diversity and intellectual capital to firm value. The research using purposive sampling method where from 153 manufacturing companies listed in Indonesia Stock Exchange become the population obtained 56 companies for 5 consecutive years, so the total sample is 280 samples. By using multiple regression analysis, it is found that the existence of foreign commissioner board and intellectual capital has a significant positive effect on firm value. However, the existence of female commissioners, education background, age, and proportion of independent board has no effect on firm value.

Keywords: Board diversity, intellectual capital, Tobin's Q, VAIC ${ }^{T M}$
\end{abstract}

\section{PENDAHULUAN}

Persaingan bisnis yang kian kompetitif dari waktu ke waktu menyebabkan perusahaan yang ada saat ini harus mempertahankan kelangsungan bisnisnya. Timbulnya persaingan ini dikarenakan semakin banyaknya perusahaan yang muncul dengan bidang yang sama namun memiliki kemampuan yang berbeda. Pada Tabel 1. dapat dilihat bahwa perusahaan yang terdaftar dari tahun 2012-2016 
I Gusti Agung Rai Kristina dan I Dewa Nyoman Wiratmaja. Pengaruh ...

mengalami peningkatan. Peningkatan jumlah perusahaan ini mengharuskan perusahaan untuk mampu bertahan di dalam persaingan bisnis, sehingga perusahaan harus memiliki investor yang menanamkan modalnya di perusahaan.

Tabel 1.

Perusahaan yang Terdaftar di BEI

\begin{tabular}{cc}
\hline Tahun & Jumlah Perusahaan \\
\hline 2012 & 459 \\
2013 & 483 \\
2014 & 506 \\
2015 & 521 \\
2016 & 537 \\
\hline
\end{tabular}

Sumber: Bursa Efek Indonesia, 2017

Ketertarikan seorang investor dalam menanamkan modal di suatu perusahaan biasanya didasari pada nilai perusahaan tersebut. Nilai perusahaan merupakan nilai jual suatu perusahaan dalam pasar modal (Aida dan Rahmawati, 2012). Dengan kata lain, nilai perusahaan dapat direfleksikan pada harga saham perusahaan di pasar. Apabila harga saham cenderung stabil dan terus meningkat, investor akan tertarik untuk menanamkan modalnya pada perusahaan tersebut dan akan berimbas pada nilai perusahaan yang ikut meningkat.

Tata kelola perusahaan (corporate governance) menjadi hal yang dipertimbangkan oleh investor sebelum melakukan investasi. Perusahaan yang telah menerapkan tata kelola yang baik (good corporate governance) dianggap dapat melaksanakan tugas dan tanggung jawabnya sehingga investor yakin dan akan memberi perhatian lebih pada perusahaan tersebut. Untuk menerapkan tata kelola yang baik, salah satu mekanisme dari corporate governance, yaitu komposisi dewan perusahaan. Dewan perusahaan yang dimaksud adalah dewan komisaris yang merupakan salah satu mekanisme internal di dalam corporate governance (Dwija Putri dan Ulupui, 2017:15). Di Indonesia, dewan komisaris 
diangkat dan bertanggung jawab kepada pemegang saham yang berperan penting dalam melakukan pengawasan atas tindak tanduk manajemen sehingga menentukan keberhasilan corporate governance. Adanya komposisi dewan di dalam perusahaan dianggap menjadi bukti minimal perusahaan telah melakukan good corporate governance.

Keragaman dewan komisaris dan corporate governance memiliki hubungan yang kuat dalam konteks manajemen tingkat atas. Dewan perusahaan merupakan pemimpin perusahaan yang sekaligus bertanggung jawab dalam pengambilan keputusan dan menetapkan sasaran perusahaan. Dewan perusahaan dianggap berimbang apabila anggota dewan berasal dari latar belakang yang beragam, dimana keuntungannya kinerja perusahaan akan lebih efisien (Hassan dan Marimuthu, 2016). Keberagaman dewan yang semakin tinggi akan menimbulkan gaya kognitif yang semakin beragam, sehingga akan semakin memperkaya pengetahuan, kebijaksanaan, ide, dan pendekatan yang tersedia bagi dewan perusahaan dan akan meningkatkan kualitas pengambilan keputusan kompleks (Williams dan O’Reilly, 1998).

Komposisi dewan perusahaan yang beragam lebih dikenal dengan istilah board diversity atau diversitas dewan. Diversitas dewan komisaris dibedakan menjadi dua, yaitu diversitas dewan yang dapat diamati atau demografi, seperti gender, umur, ras, dan kewarganegaraan serta yang tidak dapat diamati atau kognitif, seperti keahlian dan pengalaman (Milliken dan Martins, 1996). Diversitas gender, umur, ras, latar belakang pendidikan, dan kewarganegaraan merupakan hal yang wajib dipertimbangkan perusahaan dalam memilih siapa 
yang akan dijadikan sebagai dewan komisaris perusahaan karena diversitas dewan dipandang sebagai indikator independensi dan akuntabilitas pembuatan suatu keputusan (Maier, 2005) dan paling mudah untuk diamati. Selain itu, diversitas dipercaya dapat memengaruhi nilai finansial perusahaan dalam jangka panjang dan jangka pendek (Carter, et al., 2003; Grosvold, et al., 2007). Semakin besar persebaran dalam anggota dewan dapat menimbulkan semakin banyak konflik (Erhardt, et al., 2003), namun persebaran tersebut dapat memberikan alternatif penyelesaian terhadap suatu masalah yang semakin beragam daripada anggota dewan yang homogen (Kusumastuti, dkk., 2006).Menurut Akerlof (1970) dalam Dewi dan Wiratmaja (2017), teori signaling menjelaskan bagaimana perusahaan memberikan sinyal kepada pengguna laporan keuangan dimana sinyal yang ditangkap berupa bad news atau good news. Dilihat dari teori sinyal, dengan diterapkannya board diversity di dalam perusahaan memberikan sinyal positif atau good news kepada investor karena perusahaan dianggap telah menerapkan tata kelola yang baik di dalam perusahaan.

Diversitas gender merupakan bagian dari diversitas dewan yang paling sering diteliti. Diversitas ini berfokus pada keberadaan anggota dewan komisaris wanita di dalam perusahaan. Keberadaan wanita sebagai dewan komisaris masih dalam jumlah yang sangat rendah dalam dunia bisnis (Hassan dan Marimuthu, 2016). Keberadaan wanita yang masih sedikit dalam jajaran dewan komisaris mungkin disebabkan karena adanya pandangan yang berbeda mengenai wanita dan pria dalam memimpin suatu perusahaan. Booth dan Nolen (2010) menyatakan bahwa terdapat perbedaan pria dengan wanita dalam menghadapi preferensi 
risiko. Wanita yang cenderung menghindari risiko (risk averse) dibandingkan dengan pria yang cenderung mengambil risiko (risk taker) akan mengambil keputusan yang lebih tepat dan berisiko rendah.

Adanya dewan komisaris wanita dalam jajaran dewan perusahaan dianggap dapat meningkatkan nilai perusahaan karena dengan adanya wanita, perusahaan berarti memberikan kesempatan kepada siapapun, tanpa diskriminasi untuk menjadi bagian dari dewan perusahaan. Hal ini berarti perusahaan memberikan sinyal positif ke investor dan berdampak pada reputasi perusahaan yang meningkat. Pernyataan ini didukung dengan hasil penelitian yang dilakukan oleh Carter, et al. (2003), Miller dan Triana (2009), Molenkamp (2015), Wijaya dan Suprasto (2015), serta Krisna Dewi dan Aryista Dewi (2016) dimana diversitas gender berpengaruh positif pada nilai perusahaan. Namun, hasil yang berbeda diperoleh oleh Kusumastuti, dkk. (2006) dan Hassan dan Marimuthu (2016) yang menyatakan bahwa diversitas gender tidak berpengaruh pada nilai perusahaan. Perbedaan hasil ini kemungkinan disebabkan oleh sikap wanita yang cenderung menghindari risiko sehingga tidak memberi dampak apapun pada perusahaan.

$\mathrm{H}_{1}$ : Adanya dewan komisaris wanita akan meningkatkan nilai perusahaan.

Diversitas kewarganegaraan juga menjadi diversitas yang sebaiknya harus dipertimbangkan oleh perusahaan. Kewarganegaraan asing dianggap membawa opini dan perspektif yang beragam, bahasa, keyakinan, latar belakang keluarga, dan pengalaman profesional yang berbeda antara satu negara dan negara lain. Dilihat dari teori sinyal, adanya kewarganegaraan asing di dalam jajaran dewan 
membawa sinyal positif karena keunggulan kompetitif dewan komisaris mendapat perhatian lebih dari investor sehingga menarik minat investor untuk melakukan investasi yang berimbas pada nilai perusahaan yang ikut meningkat. Pernyataan ini didukung oleh hasil penelitian yang dilakukan oleh Jindal dan Jaiswall (2015) serta Winoto dan Supatmi (2014) yang menemukan diversitas kewarganegaraan berpengaruh positif pada nilai perusahaan. Namun, Darmadi (2011) tidak menemukan pengaruh keberadaan dewan komisaris berkewarganegaraan asing pada nilai perusahaan. Begitu juga penelitian yang dilakukan oleh Wijaya dan Suprasto (2015) tidak menemukan adanya pengaruh kebangsaan asing pada nilai perusahaan. Hal ini mungkin disebabkan oleh rendahnya jumlah dewan komisaris berkewarganegaraan asing sehingga tidak dapat membuktikan adanya pengaruh keberadaan dewan komisaris berkewarganegaraan asing pada nilai perusahaan.

$\mathrm{H}_{2}$ : Adanya dewan komisaris berkewarganegaraan asing akan meningkatkan nilai perusahaan.

Latar belakang pendidikan yang dimiliki oleh anggota dewan berpengaruh terhadap pengetahuan yang dimiliki (Kusumastuti, dkk., 2006). Hal ini menjadi sangat penting karena latar belakang pendidikan dewan yang sesuai denganbidang perusahaan akan lebih efektif dan efisien seorang dewan dalam mengambil keputusan dan dapat dengan tepat melakukan hal yang seharusnya dilakukan oleh perusahaan. Proses pemilihan dewan perusahaan harusnya mengikuti aturan dan persyaratan-persyaratan tentang pencapaian integritas, pendidikan, kompetensi, dan reputasi seseorang (Wijaya dan Suprasto, 2015). Latar belakang pendidikan yang sesuai akan membantu perusahaan untuk mendapatkan keputusan terbaik dibandingkan dengan latar belakang pendidikan yang tidak sesuai. Ditinjau dari 
teori sinyal, latar belakang pendidikan dewan komisaris yang sesuai membawa sinyal positif kepada investor karena dewan komisaris mampu melakukan pengawasan yang tepat demi kelangsungan bisnis perusahaan. Kusumastuti, dkk. (2006) menyatakan meskipun bukan menjadi suatu keharusan bagi seseorang yang akan masuk dunia bisnis untuk berpendidikan bisnis, akan lebih baik jika anggota dewan memiliki latar belakang pendidikan bisnis dan ekonomi. Keputusan yang diberikan akan memengaruhi keefektifan perusahaan dan mempermudah dalam penyelesaian masalah karena terdapat orang yang benar-benar berkompeten pada bidang bisnis. Krisna Dewi dan Aryista Dewi (2016) menemukan adanya pengaruh positif latar belakang pendidikan pada nilai perusahaan. Namun, penelitian yang dilakukan Kusumastuti, dkk. (2006), Molenkamp (2015), dan Wijaya dan Suprasto (2015) tidak menemukan latar belakang pendidikan dewan berpengaruh pada nilai perusahaan.

$\mathrm{H}_{3}$ : Semakin besar jumlah dewan komisaris berlatar belakang pendidikan ekonomi dan bisnis, maka semakin tinggi nilai perusahaan.

Umur dewan merupakan indikator diversitas dewan yang juga dapat memengaruhi nilai perusahaan. Menurut Herrmann dan Datta (2005), umur dapat dianggap sebagai proksi dari tingkat pengalaman seorang dewan dan cara pengambilan risiko. Ditinjau dari teori sinyal, umur dewan komisaris muda membawa sinyal positif kepada investor karena umur yang muda menandakan keberanian dalam mengambil risiko dan gagasan baru untuk kelangsungan hidup perusahaan. Anggota dewan yang memiliki umur lebih muda cenderung lebih berani dalam mengambil risiko dan selalu memiliki gagasan baru, sehingga perusahaan dapat mengalami pertumbuhan yang lebih tinggi dibandingkan dengan 
anggota dewan yang memiliki umur lebih tua. Ini dikarenakan anggota dewan yang lebih tua lebih mementingkan keamanan dari finansial dan karir perusahaan. Cheng, et al., (2010) menyatakan bahwa sementara dewan yang lebih muda cenderung memiliki kemampuan yang lebih tinggi untuk memproses gagasan baru, hal tersebut akan menurunkan keinginan untuk menerima status dan kurang tertarik pada stabilitas karir.

Levinson dan Peskin (1981) dalam Kusumastuti, dkk. (2006) menyatakan bahwa usia 34-50 tahun adalah kelompok usia yang paling sehat, tenang, dapat mengontrol diri, dan bertanggung jawab. Pada usia 40-45 tahun, seseorang dianggap telah menapaki jenjang karir sejauh yang mereka mampu dan telah mencapai tempat yang stabil dalam karirnya di usia 40 tahun.Darmadi (2011) menyatakan bahwa dalam jajaran anggota dewan perusahaan, dewan yang memiliki umur lebih muda ( $\leq 50$ tahun) cenderung lebih berani dalam mengambil risiko dan selalu memiliki gagasan baru, sehingga perusahaan dapat mengalami pertumbuhan yang lebih tinggi dibandingkan dengan anggota dewan yang memiliki umur lebih tua (>50 tahun). Dapat dikatakan, dengan adanya anggota dewan perusahaan berumur muda, perusahaan akan memiliki gagasan-gagasan baru yang dapat membantu perusahaan untuk berkembang, sehingga menarik minat investor untuk menanamkan modal di perusahaan. Hasil yang sama diperoleh oleh Darmadi (2011) dan Siciliano (1996) yang menyatakan umur dewan berpengaruh positif pada nilai perusahaan dimana dewan komisaris yang lebih muda cenderung berani dalam mengambil risiko dan melakukan perubahan strategi untuk meningkatkan kinerja perusahaan. Hasil penelitian berbeda 
diperoleh oleh Kusumastuti, dkk. (2006), dimana umur dewan tidak berpengaruh pada nilai perusahaan.

$\mathrm{H}_{4}$ : $\quad$ Semakin besar jumlah dewan komisaris berumur muda ( $\leq 50$ tahun), maka semakin tinggi nilai perusahaan.

Selain diversitas yang dijelaskan diatas, diversitas dewan juga dapat diproksikan pada proporsi komisaris independen di dalam perusahaan. Komisaris independen merupakan dewan komisaris yang berasal dari luar perusahaan dan memiliki sikap independensi dalam menjalankan tugasnya sebagai komisaris. Komisaris independen bertugas sebagai pengawas perilaku manajemen perusahaan yang berasal dari luar perusahaan agar manajemen tidak melakukan tindakan diluar kepentingan perusahaan. Menurut Putri dan Dwija Putri (2016), jumlah dewan komisaris independen yang semakin banyak menandakan bahwa dewan komisaris independen melakukan fungsi pengawasan dan koordinasi dalam perusahaan yang semakin baik.Perusahaan yang memiliki komisaris independen dalam jajaran dewan komisaris membawa sinyal positif kepada investor karena dianggap telah menerapkan tata kelola yang baik karena sifat independen dari komisaris ini menjadi cerminan transparansi perusahaan bagi investor. Penelitian yang dilakukan Jindal dan Jaiswall (2015) menemukan proporsi dewan komisaris independen di perusahaan berpengaruh negatif pada nilai perusahaan. Hal ini dikarekan over-monitoring yang dilakukan oleh dewan komisaris independen pada perusahaan yang telah menerapkan tata kelola yang baik (well-governed). Tetapi, penelitian yang berbeda ditemukan oleh Kusumastuti, dkk. (2006), Wijaya dan Suprasto (2015), serta Krisna Dewi dan Aryista Dewi (2016) bahwa proporsi dewan komisaris independen tidak berpengaruh pada nilai perusahaan. Hal ini 
mungkin disebabkan karena rendahnya jumlah dewan komisaris independen yang berada di dalam jajaran dewan komisaris.

$\mathrm{H}_{5}$ : Semakin besar proporsi dewan komisaris independen, maka semakin tinggi nilai perusahaan.

Selain komposisi dewan perusahaan, terdapat hal lain yang dapat memengaruhi nilai perusahaan, yaitu intellectual capital atau modal intelektual. Modal intelektual adalah aset tidak berwujud yang dapat berupa pengetahuan, informasi, pengalaman yang dimiliki oleh sumber daya manusia, dan organisasi perusahaan (Stewart \& Ruckdeschel, 1997). Terdapat dua kategori aset tidak berwujud, yaitu organizational (structural) capital dan human capital. Aida dan Rahmawati (2015) menyatakan bahwa modal intelektual mencakup semua pengetahuan karyawan, organisasi, dan kemampuan mereka untuk menciptakan nilai tambah dan menciptakan keunggulan kompetitif berkelanjutan. Menurut Kumala dan Sari (2016), perusahaan perlu menyampaikan beberapa informasi lain kepada pihak yang menggunakan laporan keuangan berkaitan dengan informasi yang dianggap memiliki nilai lebih di dalam suatu perusahan sebagai modal atau kekayaan pengetahuan (knowledge capital) atau dikenal dengan kekayaan intelektual (intellectual capital), seperti inovasi, penemuan, peningkatan pengetahuan karyawan, serta memiliki relasi yang baik kepada para konsumen.

Modal intelektual saat ini sangat penting dimiliki oleh perusahaan karena dengan kepemilikan modal intelektual oleh perusahaan dapat memunculkan value added yang dapat memberikan suatu competition advantage apabila dikomparatifkan dengan pesaingnya (Tirtha Negari dkk., 2017). Modal intelektual yang dimiliki oleh perusahaan memberikan sinyal positif kepada investor karena 
dengan perusahaan memiliki modal intelektual akan memungkinkan investor untuk menilai kemampuan perusahaan dengan lebih baik dan meminimalkan persepsi risiko yang akan terjadi di masa yang akan datang. Penelitian yang dilakukan oleh Chatzoudes, et al. (2011) menunjukkan adanya pengaruh yang signifikan antara human capital dengan nilai perusahaan. Hasil yang sama juga diperoleh Sudibya dan Restuti (2014), Berzkalne dan Zelgalve (2014), Nuryaman (2015), dan Bemby S., et al. (2015) dimana modal intelektual berpengaruh positif pada nilai perusahaan.

$\mathrm{H}_{6}$ : Semakin tinggi intellectual capital yang dimiliki perusahaan, maka semakin tinggi nilai perusahaan.

\section{METODE PENELITIAN}

Desain penelitian yang digunakan dalam penelitian ini adalah pendekatan kuantitatif yang berbentuk asosiatif. Sugiyono (2014) menyatakan bahwa penelitian asosiatif adalah penelitian yang bertujuan untuk mengetahui hubungan dua variabel atau lebih. Penelitian ini menguji pengaruh board diversity yang diproksikan pada keberadaan dewan komisaris wanita, keberadaan dewan komisaris berkewarganegaraan asing, latar belakang pendidikan dewan komisaris, umur dewan komisaris, dan proporsi dewan komisaris independen, serta intellectual capital pada nilai perusahaan. Penelitian ini dilakukan pada perusahaan sektor manufaktur yang terdaftar di Bursa Efek Indonesia (BEI) tahun 2012-2016 melalui situs www.idx.co.id dan mengakses situs perusahaan masingmasing. Obyek pada penelitian ini adalah nilai perusahaan pada perusahaan manufaktur yang terdaftar di Bursa Efek Indonesia (BEI) tahun 2012- 
2016.Terdapat dua jenis variabel yang digunakan dalam penelitian ini, yaitu variabel dependen (Y) dan variabel independen (X).

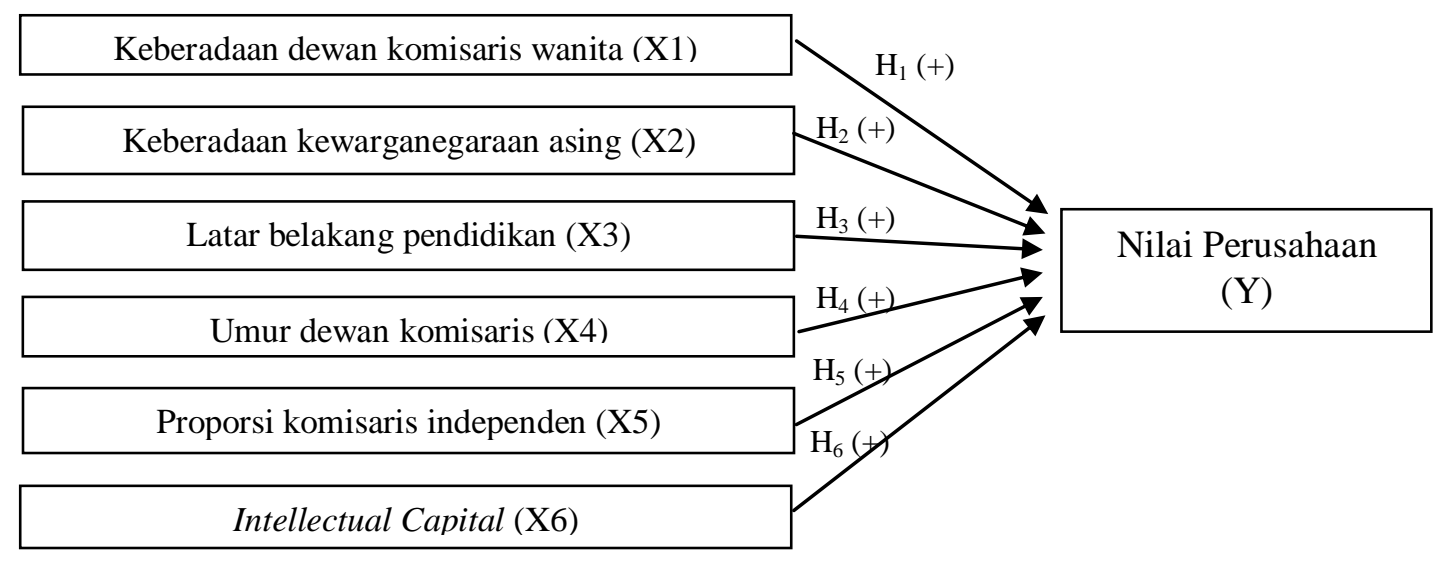

\section{Gambar 1. Desain Penelitian}

Sumber : Data diolah, 2017

Variabel dependen (Y) dalam penelitian ini adalah nilai perusahaan yang diukur menggunakan rasio Tobin's $Q$. Jika nilai yang diperoleh dari rasio Tobin's $Q<1$, berarti saham perusahaan dalam kondisi undervalued. Nilai tersebut menunjukkan potensi pertumbuhan investasi yang rendah dan manajemen telah gagal mengelola aktiva perusahaan. Nilai yang diperoleh dari rasio Tobin's $Q=1$, berarti saham perusahaan dalam kondisi average. Nilai tersebut menunjukkan potensi pertumbuhan investasi tidak berkembang dan manajemen stagnan dalam mengelola aktiva. Apabila nilai yang diperoleh dari rasio Tobin's $Q>1$, berarti saham perusahaan dalam kondisi overvalued. Nilai tersebut menunjukkan potensi pertumbuhan investasi yang tinggi dan manajemen berhasil dalam mengelola aktiva. Dilihat dari ketiga interpretasi ini, investor dapat mengambil keputusan untuk menjual, membeli, atau menahan saham yang dimilikinya. Rasio Tobin's $Q$ juga dinilai dapat memberikan informasi paling baik diantara pengukuran nilai 
perusahaan lainnya karena rasio ini bisa menjelaskan berbagai fenomena dalam kegiatan perusahaan, seperti terjadinya perbedaan cross-sectional dalam pengambilan keputusan investasi dan diversifikasi, hubungan antara kepemilikan saham manajemen dan nilai perusahaan, hubungan antara kinerja manajemen dengan keuntungan dalam akuisisi, dan kebijakan pendanaan, dividen, serta kompensasi (Sukamulja, 2004).

Variabel independen $(\mathrm{X})$ dalam penelitian ini adalah keberadaan dewan komisaris wanita $\left(\mathrm{X}_{1}\right)$ yang diukur menggunakan variabel dummy, keberadaan dewan komisaris berkewarganegaraan asing $\left(\mathrm{X}_{2}\right)$ yang diukur menggunakan variabel dummy, latar belakang pendidikan dewan komisaris $\left(\mathrm{X}_{3}\right)$ yang diukur dengan membandingkan jumlah anggota dewan komisaris yang memiliki latar belakang pendidikan ekonomi dan bisnis dengan jumlah seluruh anggota dewan komisaris perusahaan, umur dewan komisaris $\left(\mathrm{X}_{4}\right)$ yang diukur dengan membandingkan jumlah anggota dewan yang memiliki umur $\leq 50$ tahun dengan jumlah seluruh anggota dewan komisaris perusahaan, proporsi dewan komisaris independen $\left(\mathrm{X}_{5}\right)$ yang diukur dengan membandingkan jumlah komisaris independen dengan jumlah seluruh anggota dewan komisaris perusahaan, dan intellectual capital $\left(\mathrm{X}_{6}\right)$ yang diukur menggunakan perhitungan $\mathrm{VAIC}^{\mathrm{TM}}$ yang terdiri atas beberapa tahap.Pengukuran intellectual capital menggunakan model ini relatif mudah karena dikonstruksikan dari akun-akun dalam laporan keuangan. Perhitungannya dimulai dari kemampuan menciptakan VA karena VA merupakan indikator paling obyekif untuk menilai keberhasilan bisnis dan menunjukkan kemampuan perusahaan dalam menciptakan nilai. 
Teknik purposivesampling digunakan dalam pemilihan sampel penelitian ini dengan kriteria sebagai berikut: (1) Perusahaan manufaktur terdaftar di Bursa Efek Indonesia (BEI) dan tidak mengalami delisting pada periode 2012-2016 dan (2) Terdapat informasi mengenai gender, kewarganegaraan, latar belakang pendidikan, umur dewan komisaris, dan proporsi dewan komisaris independen dalam annual report. Berdasarkan teknik tersebut, maka diperoleh 56 perusahaan sebagai sampel penelitian.Teknik analisis data yang digunakan dalam penelitian ini adalah uji asumsi klasik dan analisis regresi linear berganda. Adapun rumus analisis data tersebut digambarkan dalam persamaan regresi sebagai berikut.

$$
Y=\alpha+\beta_{1} \cdot X_{1}+\beta_{2} \cdot X_{2}+\beta_{3} \cdot X_{3}+\beta_{4} \cdot X_{4}+\beta_{5} \cdot X_{5}+\beta_{6} \cdot X_{6}+\varepsilon
$$

Keterangan:

\begin{tabular}{|c|c|}
\hline Y & $=$ Nilai Perusahaan \\
\hline$\alpha$ & $=$ Nilai konstanta \\
\hline$\beta_{1}, \beta_{2}, \beta_{3}$ & $=$ Koefisien regresi variabel independen \\
\hline $\mathrm{X}_{1}$ & $=$ Keberadaan dewan komisaris wanita \\
\hline $\mathrm{X}_{2}$ & = Keberadaan dewan komisaris berkewarganegaraan asing \\
\hline $\mathrm{X}_{3}$ & = Latar belakang pendidikan dewan komisaris \\
\hline $\mathrm{X}_{4}$ & $=$ Umur dewan komisaris \\
\hline $\mathrm{X}_{5}$ & $=$ Proporsi dewan komisaris independen \\
\hline $\mathrm{X}_{6}$ & $=$ Intellectual Capital \\
\hline & $=$ Error term, yaitu tingkat kesalahan penduga dalam penelitian \\
\hline
\end{tabular}

\section{HASIL DAN PEMBAHASAN}

Statistik deskriptif disajikan untuk memberikan informasi mengenai karakteristik variabel-variabel penelitian, antara lain nilai minimum, maksimum, rata-rata, dan simpangan baku.Adapun hasil statistik deskriptif setiap variabel dapat dilihat pada Tabel 2. 
Tabel 2.

Hasil Statistik Deskriptif Variabel Penelitian

\begin{tabular}{cccccc}
\hline Variabel & N & Min. & Maks. & Rata-rata & Simpangan Baku \\
\hline $\mathrm{Y}$ & 280 & 0,33 & 7,11 & 1,4167 & 1,16238 \\
$\mathrm{X}_{1}$ & 280 & 0,00 & 1,00 & 0,3000 & 0,45908 \\
$\mathrm{X}_{2}$ & 280 & 0,00 & 1,00 & 0,2929 & 0,45589 \\
$\mathrm{X}_{3}$ & 280 & 0,00 & 100,00 & 48,8969 & 31,46634 \\
$\mathrm{X}_{4}$ & 280 & 0,00 & 100,00 & 20,2253 & 24,58731 \\
$\mathrm{X}_{5}$ & 280 & 0,00 & 80,00 & 36,4142 & 13,71436 \\
$\mathrm{X}_{6}$ & 280 & $-3,82$ & 9,71 & 2,8580 & 1,68780 \\
\hline
\end{tabular}

Sumber: Data diolah, 2017

Berdasarkan Tabel 2, diketahui bahwa terdapat tujuh variabel penelitian, yaitu keberadaan dewan komisaris wanita, keberadaan dewan komisaris berkewarganegaraan asing, latar belakang pendidikan dewan komisaris, umur dewan komisaris, proporsi dewan komisaris independen, intellectual capital, dan nilai perusahaan yang diproksikan dengan Tobin's Q.Data pada variabel nilai perusahaan (Y) berjumlah 280 dengan nilai rata-rata sebesar 1,4167 dan simpangan baku sebesar 1,16238. Nilai minimum pada variabel nilai perusahaan diperoleh pada Jaya Pari Steel Tbk. sebesar 0,33, sedangkan nilai maksimum diperoleh pada Kalbe Farma Tbk. sebesar 7,11.

Data pada variabel keberadaan dewan komisaris wanita $\left(\mathrm{X}_{1}\right)$ berjumlah 280 dengan nilai rata-rata sebesar 0,3000 dan simpangan baku sebesar 0,45908. Nilai minimum pada variabel keberadaan dewan komisaris wanita diperoleh sebesar 0,00, sedangkan nilai maksimum diperoleh sebesar 1,00.Data pada variabel keberadaan dewan komisaris berkewarganegaraan asing $\left(\mathrm{X}_{2}\right)$ berjumlah 280 dengan nilai rata-rata sebesar 0,2929 dan simpangan baku sebesar 0,45589. Nilai minimum pada variabel keberadaan dewan komisaris berkewarganegaraan asing diperoleh sebesar 0,00, sedangkan nilai maksimum diperoleh sebesar 1,00. 
I Gusti Agung Rai Kristina dan I Dewa Nyoman Wiratmaja. Pengaruh ...

Data pada variabel latar belakang pendidikan dewan komisaris $\left(\mathrm{X}_{3}\right)$ berjumlah 280 dengan nilai rata-rata sebesar 48,8969 dan simpangan baku sebesar 31,46634. Nilai minimum pada variabel latar belakang pendidikan dewan komisaris diperoleh sebesar 0,00 persen, sedangkan nilai maksimum diperoleh sebesar 100,00 persen. Data pada variabel umur dewan komisaris $\left(\mathrm{X}_{4}\right)$ berjumlah 280 dengan nilai rata-rata sebesar 20,2253 dan simpangan baku sebesar 24,58731. Nilai minimum pada variabel umur dewan komisaris diperoleh sebesar 0,00 persen, sedangkan nilai maksimum sebesar 100,00 persen.

Data pada variabel proporsi dewan komisaris independen $\left(\mathrm{X}_{5}\right)$ berjumlah 280 dengan nilai rata-rata sebesar 36,4142 dan simpangan sebesar 13,71436. Nilai minimum pada variabel proporsi dewan komisaris independen diperoleh sebesar 0,00, sedangkan nilai maksimum diperoleh sebesar 80,00.Data pada variabel intellectual capital $\left(\mathrm{X}_{6}\right)$ berjumlah 280 dengan nilai rata-rata sebesar 2,8580 dan simpangan baku sebesar 1,68780. Nilai minimum pada variabel intellectual capital diperoleh pada SLJ Global Tbk. sebesar -3,82, sedangkan nilai maksimum diperoleh pada Multi Prima Sejahtera Tbk. sebesar 9,71.

Analisis data dalam penelitian ini menggunakan metode analisis regresi berganda. Analisis regresi berganda digunakan untuk mengetahui dan menunjukkan arah serta besarnya pengaruh keberadaan dewan komisaris wanita, keberadaan dewan komisaris berkewarganegaraan asing, latar belakang pendidikan dewan komisaris, umur dewan komisaris, proporsi dewan komisaris independen, dan intellectual capital baik secara simultan maupun parsial terhadap 
nilai perusahaan perusahaan manufaktur yang terdaftar di Bursa Efek Indonesia. Hasil analisis regresi linear berganda disajikan pada Tabel 3.

Tabel 3.

Hasil Analisis Regresi Linear Berganda

\begin{tabular}{|c|c|c|c|c|c|c|}
\hline \multirow{2}{*}{\multicolumn{2}{|c|}{ Model }} & \multicolumn{2}{|c|}{$\begin{array}{c}\text { Unstandardized } \\
\text { Coefficients }\end{array}$} & \multirow{2}{*}{$\begin{array}{c}\begin{array}{c}\text { Standardized } \\
\text { Coefficients }\end{array} \\
\text { Beta }\end{array}$} & \multirow[t]{2}{*}{$\mathbf{t}$} & \multirow[t]{2}{*}{ Sig. } \\
\hline & & B & Std. Error & & & \\
\hline \multirow[t]{7}{*}{1} & (Constant) & 0,987 & 0,288 & & 3,431 & 0,001 \\
\hline & $\mathrm{X}_{1}$ & $-0,035$ & 0,150 & $-0,014$ & $-0,236$ & 0,814 \\
\hline & $\mathrm{X}_{2}$ & 0,350 & 0,151 & 0,137 & 2,325 & 0,021 \\
\hline & $\mathrm{X}_{3}$ & $-0,003$ & 0,002 & $-0,089$ & $-1,427$ & 0,155 \\
\hline & $\mathrm{X}_{4}$ & 0,003 & 0,003 & 0,063 & 1,026 & 0,306 \\
\hline & $\mathrm{X}_{5}$ & $-0,005$ & 0,005 & $-0,056$ & $-0,920$ & 0,358 \\
\hline & $\mathrm{X}_{6}$ & 0,163 & 0,040 & $-0,236$ & 4,055 & 0,000 \\
\hline
\end{tabular}

F hitung $\quad: 4,156$

Signifikansi F : $\quad 0,001$

R Square $\quad: 0,084$

Adjusted R Square : $\quad 0,064$

Sumber : Data diolah, 2017

Koefisien determinasi pada model regresi linear berganda dilihat dari nilai

Adjusted $R$-Square sebesar 0,064, yang berarti secara bersama-sama keberadaan dewan komisaris wanita, keberadaan dewan komisaris berkewarganegaraan asing, latar belakang pendidikan dewan komisaris, umur dewan komisaris, proporsi dewan komisaris independen, dan intellectual capital berpengaruh sebesar 6,4\%, sedangkan sisanya sebesar 93,6\% dipengaruhi oleh variabel lain yang tidak masuk dalam model.

Uji F merupakan tahapan awal mengidentifikasi model regresi yang diestimasi layak atau tidak.Berdasarkan Tabel 3 diatas, diperoleh nilai signifikansi sebesar 0,001 dimana nilai sig. $0,001<0,05$, maka hal ini berarti seluruh variabel mampu menjelaskan fenomena nilai perusahaan pada perusahaan manufaktur dan model regresi yang digunakan dianggap layak uji. 
Tabel 3 menunjukkan koefisien keberadaan dewan komisaris wanita $\left(\beta_{1}\right)$ sebesar -0,035 dengan nilai signifikansi 0,814 lebih besar dari $\alpha(0,814>0,05)$, maka $\mathrm{H}_{0}$ diterima dan $\mathrm{H}_{1}$ ditolak. Hasil ini menunjukkan bahwa keberadaan dewan komisaris wanita secara parsial tidak berpengaruh signifikan terhadap nilai perusahaan. Tidak adanya pengaruh keberadaan dewan komisaris wanita pada nilai perusahaan kemungkinan disebabkan oleh tidak adanya perbedaan dalam kinerja perusahaan dari perspektif keragaman gender. Menurut Gallego-Álvarez, et al. (2010), keragaman gender tidak serta merta memengaruhi peningkatan nilai perusahaan. Perusahaan dengan tingkat keragaman gender yang lebih tinggi tidak selalu memperoleh nilai perusahaan yang lebih tinggi karena keragaman gender yang muncul dalam jajaran dewan komisaris mungkin lebih mudah dijelaskan dari perspektif sosiologis dibandingkan perspektif ekonomi.

Tabel 3 menunjukkan koefisien keberadaan dewan komisaris berkewarganegaraan asing $\left(\beta_{2}\right)$ sebesar 0,350 dengan tingkat signifikansi sebesar 0,021 dengan $(\alpha)=5$ persen $(0,021<0,05)$, maka $\mathrm{H}_{0}$ ditolak dan $\mathrm{H}_{2}$ diterima. Ini berarti bahwa keberadaan dewan komisaris berkewarganegaraan asing secara parsial berpengaruh positif dan signifikan terhadap nilai perusahaan. Menurut Winoto dan Supatmi (2014), dewan komisaris berkewarganegaraan asing dapat membawa opini dan perspektif yang beragam, bahasa, keyakinan, latar belakang keluarga, dan pengalaman profesional yang berbeda antara satu negara dengan negara lain. Adanya kewarganegaraan asing dalam dewan komisaris juga diharapkan dapat membawa keunggulan kompetitif pada perusahaan, dimana keunggulan kompetitif ini tentunya akan dapat meningkatkan nilai perusahaan. 
Jindal dan Jaiswall (2015) menyatakan adanya dewan komisaris berkewarganegaraan asing dalam jajaran dewan dianggap baik dan dewan komisaris berkewarganegaraan asing cenderung dihargai dibandingkan dengan perusahaan yang dalam jajaran dewannya tidak terdapat dewan berkewarganegaraan asing.

Tabel 3 menunjukkan koefisien latar belakang pendidikan dewan komisaris $\left(\beta_{3}\right)$ sebesar $-0,003$ dengan tingkat signifikansi sebesar 0,155 dengan $(\alpha)$ $=5$ persen $(0,155>0,05)$, maka $\mathrm{H}_{0}$ diterima dan $\mathrm{H}_{3}$ ditolak. Ini berarti bahwa latar belakang pendidikan dewan komisaris secara parsial tidak berpengaruh signifikan terhadap nilai perusahaan. Hal ini dikarenakan perusahaan manufaktur sebagai lokasi penelitian didominasi oleh dewan komisaris berlatar belakang pendidikan teknik dibandingkan dewan komisaris berlatar belakang pendidikan ekonomi dan bisnis. Perusahaan manufaktur yang identik dengan pengaplikasian mesin dan peralatan tentunya lebih memerlukan pihak yang paham dalam hal tersebut, sehingga latar belakang pendidikan dalam jajaran dewan lebih banyak terisi oleh dewan berlatar belakang pendidikan teknik. Selain itu, dalam menjalankan perusahaan tentunya diperlukan soft skill yang sesuai dengan bidang perusahaan diluar hard skill yang diperoleh pada bangku pendidikan. Hasil tidak berpengaruh signifikan ini juga kemungkinan disebabkan oleh metode pengukuran yang kurang tepat. Untuk mengetahui diversitas di dalam perusahaan berpengaruh atau tidak pada nilai perusahaan, proporsi anggota dewan dengan atribut tertentu bukanlah ukuran keragaman yang sesuai (Campbell dan Mínguez- 
Vera, 2008), sehingga pengukuran diversitas yang lebih tepat digunakan adalah Indeks Blau.

Tabel 3 menunjukkan koefisien umur dewan komisaris $\left(\beta_{4}\right)$ sebesar 0,003 dengan tingkat signifikansi sebesar 0,306 dengan $(\alpha)=5$ persen $(0,306>0,05)$, maka $\mathrm{H}_{0}$ diterima dan $\mathrm{H}_{4}$ ditolak. Ini berarti bahwa umur dewan komisaris secara parsial tidak berpengaruh signifikan terhadap nilai perusahaan. Tidak adanya pengaruh signifikan umur dewan komisaris pada nilai perusahaan kemungkinan dikarenakan kemampuan dan kinerja dewan komisaris tidak dapat diukur hanya dengan umur, melainkan dengan pengalaman. Dewan komisaris berumur lebih muda walaupun cenderung lebih berani dalam mengambil risiko dan selalu memiliki gagasan baru, dalam hal pengalaman yang lebih banyak dan beragam masih kurang dibandingkan dengan dewan komisaris berumur lebih tua. Selain itu, nilai perusahaan yang diproksikan pada harga saham tidak hanya dipengaruhi oleh proporsi dewan komisaris muda, melainkan dipengaruhi juga oleh perilaku pasar.

Tabel 3 menunjukkan koefisien proporsi dewan komisaris independen $\left(\beta_{5}\right)$ sebesar $-0,005$ dengan tingkat signifikansi sebesar 0,358 dengan $(\alpha)=5$ persen $(0,358>0,05)$, maka $\mathrm{H}_{0}$ diterima dan $\mathrm{H}_{5}$ ditolak. Ini berarti bahwa proporsi dewan komisaris independen secara parsial tidak berpengaruh signifikan terhadap nilai perusahaan. Tidak adanya pengaruh dewan komisaris independen pada nilai perusahaan walaupun sebagian besar telah sesuai dengan peraturan kemungkinan disebabkan oleh keterpaksaan perusahaan memenuhi peraturan atau regulasi yang telah ditetapkan karena bersifat wajib (mandatory). Hal ini menyebabkan dewan 
komisaris independen tidak memiliki keterlibatan yang tinggi dalam pengambilan keputusan karena adanya pembatasan dalam hal tersebut. Pembatasan pengambilan keputusan ini disebabkan oleh diabaikannya integritas dan kompetensi dewan komisaris independen.

Tabel 3 menunjukkan koefisien intellectual capital $\left(\beta_{6}\right)$ sebesar 0,163 dengan tingkat signifikansi sebesar 0,000 dengan $(\alpha)=5$ persen $(0,000<0,05)$, maka $\mathrm{H}_{0}$ ditolak dan $\mathrm{H}_{6}$ diterima. Ini berarti bahwa intellectual capital secara parsial berpengaruh positif dan signifikan terhadap nilai perusahaan. Adanya intellectual capital merupakan bukti dari transparansi perusahaan sehingga investor akan lebih mudah menilai prospek perusahaan kedepannya. Secara teori, kekayaan intelektual yang dikelola secara efisien oleh perusahaan akan meningkatkan apresiasi pasar terhadap nilai pasar sehingga meningkatkan nilai perusahaan (Sudibya dan Restuti, 2014). Bemby S., et al. (2015) juga menyatakan bahwa semakin efektif dan efisien manajemen dan penggunaan modal intelektual akan meningkatkan nilai perusahaan. Pengaruh positif dan signifikan intellectual capital pada nilai perusahaan mengindikasikan bahwa perusahaan mampu mengelola aset dengan baik sehingga dapat mengurangi biaya operasional dan meningkatkan nilai tambah dari hasil kemampuan intelektual perusahaan.

\section{SIMPULAN}

Berdasarkan hasil penelitian yang diperoleh melalui pengujian statistik dan pembahasan, maka dapat disimpulkan bahwa keberadaan dewan komisaris wanita, latar belakang pendidikan dewan komisaris, umur dewan komisaris, dan proporsi dewan komisaris independen tidak berpengaruh pada nilai perusahaan. 
I Gusti Agung Rai Kristina dan I Dewa Nyoman Wiratmaja. Pengaruh ...

Sedangkan, keberadaan dewan komisaris berkewarganegaraan asing dan intellectual capital berpengaruh positif signifikan pada nilai perusahaan.

Berdasarkan hasil penelitian dan simpulan diatas, maka saran yang dapat diberikan adalah lokasi penelitian yang terbatas hanya pada perusahaan manufaktur yang terdaftar di Bursa Efek Indonesiaagar dapat dilakukan pada sektor perusahaan yang berbeda, seperti sektor pertambangan, sektor pertanian, sektor properti, sektor perdagangan, dan lain-lain. Selain itu, pengukuran diversitas dewan diharapkan menggunakan proksi yang berbeda, seperti Indeks Blau sehingga mendapatkan ukuran yang lebih baik dalam mengukur heterogenitas pada karakteristik katagorikal. Penggunaan variabel lain seperti sepertikeahlian dan pengalaman yang dapat memengaruhi nilai perusahaan juga dapat dilakukan dalam penelitian selanjutnya.

\section{REFERENSI}

Aida, R. N., dan Rahmawati, E. 2015. Pengaruh Modal Intelektual dan Pengungkapannya Terhadap Kinerja Perusahaan. Jurnal Akuntansi \& Investasi, 16(2), 96-109. https://doi.org/10.18196/JAI-2015.0035

Bemby S., B., Mukhtaruddin, Hakiki, A., and Ferdianti, R. 2015. Intellectual Capital, Firm Value and Ownership Structure as Moderating Variable: Empirical Study on Banking Listed in Indonesia Stock Exchange Period 2009-2012. Asian Social Science, 11(16), 148-159. https://doi.org/10.5539/ass.v11n16p148

Berzkalne, I., and Zelgalve, E. 2014. Intellectual Capital and Company Value. Procedia - Social and Behavioral Sciences, 110, 887-896. https://doi.org/10.1016/j.sbspro.2013.12.934

Booth, A. L., and Nolen, P. 2010. Gender Di a erences in Risk Behaviour : Does Nurture, 122, 56-78. https://doi.org/10.1111/j.1468-0297.2011.02480.x.

Campbell, K., and Mínguez-Vera, A. 2008. Gender diversity in the boardroom and firm financial performance. Journal of Business Ethics, 83(3), 435-451. 
https://doi.org/10.1007/s10551-007-9630-y

Carter, D. A., Simkins, B. J., and Simpson, W. G. 2003. Corporate Governance, Board Diversity, and Firm Value. The Financial Review, 38, 33-53. https://doi.org/10.1111/1540-6288.00034

Chatzoudes, D., Maditinos, D., Theriou, G., and Tsairidis, C. 2011. The impact of intellectual capital on firms' market value and financial performance. Journal of Intellectual Capital, 12(1), 132-151. https://doi.org/10.1108/14691931111097944

Cheng, L. T. W., Chan, R. Y. K., and Leung, T. Y. 2010. Management Demography and Corporate Performance: Evidence from China. International Business Review, 19(3), 261-275. https://doi.org/10.1016/j.ibusrev.2009.12.007

Darmadi, Salim. 2011. Board diversity and firm performance: The indonesian evidence. Corporate Ownership and Control, 9(1F), 524-539. https://doi.org/10.1007/s13398-014-0173-7.2

Dewi, N. M. W. P., dan Wiratmaja, I. D. N. 2017. Pengaruh Profitabilitas dan Solvabilitas pada Audit Delay dengan Ukuran Perusahaan sebagai Variabel Pemoderasi. E-Jurnal Akuntansi Universitas Udayana, 20(1), 409-437.

Dwija Putri, I G. A. M. Asri., dan Ulupui, I G. Ketut Agung. 2017. Pengantar Corporate Governance. Denpasar: CV. Sastra Utama.

Erhardt, N. L., Werbel, J. D., and Shrader, C. B. 2003. Board of Director Diversity and Firm Financial Performance. Iowa State University Digital Repository, 11(2), 102-111. https://doi.org/10.1111/1467-8683.00011

Gallego-Álvarez, I., García-Sánchez, I. M., and Rodríguez-Dominguez, L. 2010. The Influence of Gender Diversity on Corporate Performance. Revista de Contabilidad, 13(1), 53-88. https://doi.org/10.1016/S1138-4891(10)70012-1

Ghozali, Imam. 2013. Aplikasi Analisis Multivariate Dengan Program SPSS. Edisi Ketujuh. Semarang: Badan Penerbit Universitas Diponegoro.

Grosvold, J., Brammer, S., and Rayton, B. 2007. Board diversity in the United Kingdom and Norway: an exploratory analysis. Business Ethics, 16(4), 344. https://doi.org/10.1111/j.1467-8608.2007.00508.x

Hassan, R., and Marimuthu, M. 2016. Corporate Governance, Board Diversity, and Firm Value : Examining Large Companies Using Panel Data Approach. Economics Bulletin, 36(3), 1737-1750. 
Herrmann, P., and Datta, D. K. 2005. Relationships between Top Management Team Characteristics and International Diversification: an Empirical Investigation. British Journal of Management, 16(1), 69-78. https://doi.org/10.1111/j.1467-8551.2005.00429.x

Jindal, V., and Jaiswall, M. 2015. Board Diversity and Firm Performance Influenced by Ownership Concentration : Evidence from India, (765), 1-21.

Krisna Dewi, L. G., dan Aryista Dewi, A. 2016. Pengaruh Diversitas Dewan Komisaris dan Direksi pada Nilai Perusahaan pada Perusahaan Sektor Keuangan yang Terdaftar di Bursa Efek Indonesia Tahun 2009-2013. EJurnal Akuntansi Universitas Udayana, 16(1), 812-836.

Kumala, K. S., dan Sari, Maria M. Ratna. 2016. Pengaruh Ownership Retention, Leverage, Tipe Auditor, Jenis Industri terhadap Pengungkapan Intellectual Capital. E-Jurnal Akuntansi Universitas Udayana, 14(1), 1-18.

Kusumastuti, S., Supatmi, dan Sastra, P. 2014. Pengaruh Board Diversity Terhadap Nilai Perusahaan Dalam Perspektif Corporate Governance. Jurnal Akuntansi Dan Keuangan, 9(2), 88-98. Retrieved from http://puslit2.petra.ac.id/ejournal/index.php/aku/article/view/16819

Maier, S. 2005. How Global is Good Corporate Governance. London: Ethical Investment Research Services, 1-20. Retrieved from http://www.eiris.org/files/research publications/howglobalisgoodcorpgov05.pdf

Miller, T., and Triana, M. del C. 2009. Demographic Diversity in the Boardroom: Mediators of the Board Diversity - Firm Performance Relationship. Journal of Management Studies, 46(5), 754-786.

Milliken, F. J., and Martins, L. L. 1996. Searching for Common Treads: Undertanding The Multiple Effects of in Organizational Diversity. Academy of Management, 21(2), 402-433. https://doi.org/10.5465/AMR.1996.9605060217

Molenkamp, J. 2015. Board diversity and firm performance: The Dutch evidence. 5th IBA Bachelor Thesis Conference, Netherlands., 1-13. https://doi.org/10.1007/s13398-014-0173-7.2

Nuryaman. 2015. The Influence of Intellectual Capital on The Firm's Value with The Financial Performance as Intervening Variable. Procedia - Social and Behavioral Sciences, 211(September), 292-298. https://doi.org/10.1016/j.sbspro.2015.11.037 
Peraturan Otoritas Jasa Keuangan No. 33/POJK.04/2014 tentang Direksi dan Dewan Komisaris Emiten atau Perusahaan Publik.

Putri, P. S. U., dan Dwija Putri, I G. A. M. Asri. 2016. Opini Auditor sebagai Pemoderasi Pengaruh Good Corporate Governance pada Nilai Perusahaan Perbankan Tahun 2012-2014. E-, 17(1), 29-55.

Randa, F., dan Solon, S. A. 2012. Pengaruh Modal Intelektual terhadap Nilai Perusahaan (Studi Empiris pada Perusahaan Manufaktur yang Terdaftar di Bursa Efek Indonesia). Jurnal Sistem Informasi Manajemen Dan Akuntansi, 10(1), h:24-47.

Siciliano, J. I. 1996. The relationship of board member diversity to organizational performance. Journal of Business Ethics, 15(12), 1313-1320. https://doi.org/10.1007/BF00411816

Stewart, T., and Ruckdeschel, C. 1997. Intellectual Capital: The New Wealth of Organizations. Performance Improvement.

Sudibya, D. C. N. A., dan Restuti, M. M. D. 2014. Pengaruh Modal Intelektual Terhadap Nilai Perusahaan dengan Kinerja Keuangan sebagai Variabel Intervening. BENEFIT Jurnal Manajemen Dan Bisnis, 18(1), 14-29.

Sukamulja, S.2004. Good Corporate Governance Di Sektor Keuangan: Dampak GCG Terhadap Kinerja Perusahaan (Kasus di Bursa Efek Jakarta). BENEFIT Jurnal Manajemen Dan Bisnis Fakultas Ekonomi Universitas Atma Jaya Yogyakarta, 8(1), 1-25.

Tirtha Negari, N. P. A. S., Suartana, I. W., dan Tenaya, A. I. 2017. Pengaruh Profil Risiko dan Modal Intelektual pada Return On Assets Perbankan. EJurnal Akuntansi Universitas Udayana, 18(3), 2231-2259.

Wahyuni, M. A., dan Rasmini, N. K. 2016. Pengaruh Mekanisme Corporate Governance pada Pengungkapan Modal Intelektual (Studi Empiris pada Perusahaan Manufaktur yang Terdaftar di Bursa Efek Indonesia). Jurnal Buletin Studi Ekonomi, 21(1), h:48-59.

Wijaya, P. C., dan Suprasto, B. 2015. Pengaruh Persebaran Dewan Two Tier (Dewan Gabungan) Pada Nilai Perusahaan Sektor Keuangan. E-Jurnal Akuntansi Universitas Udayana, 12(3), 722-734.

Williams, K. Y., dan O'Reilly, C. A. 1998. Demography and Diversity in Organizations: A Review of 40 Years off Research. Research in Organizational Behavior. https://doi.org/10.1177/104649640003100505 
I Gusti Agung Rai Kristina dan I Dewa Nyoman Wiratmaja. Pengaruh ...

Winoto, P. J., dan Supatmi. 2014. Pengaruh Diversitas Kebangsaan Board of Director Terhadap Nilai Perusahaan, (2008), 1-10. 